\title{
New reports on our Nation's water quality
}

The U. S. Geological Survey National WaterQuality Assessment (NAWQA) Program recently released the last 15 of 51 reports on water quality in major river basins and aquifers across the Nation. NAWQA began assessing the quality of our streams, ground water, and aquatic ecosystems in 1991.

Collectively, the new reports characterize the general health of our ground- and surface-water resources, address current and emerging water issues and priorities, and describe trends in water quality-a wealth of information that contributes to practical and effective water-resource management. Selected findings of regional and national interest are highlighted in a separate report, Water Quality in the Nation's Streams and Aquifers-Overview of Selected Findings, 1991-2001.

NAWQA assessments indicate that the Nation's waters generally are suitable for irrigation, drinkingwater supply, and other home and recreational uses. Major challenges that continue to affect streams and ground water in parts of every study unit include point and nonpoint sources of pesticides, nutrients, metals, gasoline-related compounds, and other contaminants.

These assessments use a nationally consistent design and methodology so that water-resource managers can compare water quality in their basins to other areas in the Nation. The assessments also delineate the effects of natural factors and human activities on water resources, such as effects associated with agriculture and urban development. Contaminant levels vary from season to season and among watersheds because of differences in land and chemical use, land-management practices, degree of watershed development, and natural features, such as soils, geology, hydrology, and climate. Using this information, decision makers can implement costeffective water-management strategies in specific geographic areas.

\section{Selected highlights from NAWOA reports}

Changes in land management can improve streamwater quality. For example, best management practices that began in the 1990s in much of the Yakima River Basin, Washington (such as converting from rill, or "furrow," irrigation to sprinkler and drip irrigation) have reduced runoff from farm fields, thus reducing suspended sediment, total phosphorus, dissolved nitrate, and organochlorine compounds (such as DDT) in streams. Concentrations of total DDT (DDT and its stable breakdown products) in largescale suckers, smallmouth bass, and carp from the lower Yakima River decreased by about half from the late 1980s to 1998 .

Ground-water quality also responds to changes in land management, but usually more slowly than surface water. USGS ground-water age-dating techniques used on the Delmarva Peninsula (Delaware, Maryland, and Virginia) indicate that improvements in ground-water quality, including reduced concentrations of nitrate from agricultural fertilizers, can lag behind land-management changes by decades because of the slow rate of ground-water flow.

Urbanizing watersheds show positive and negative changes in water quality. NAWQA sampled sediment cores from 42 reservoirs and lakes in 20 metropolitan areas across the Nation from 1996 to 2001, including near Chicago, Los Angeles, Salt Lake City, and Newark. Data show decreasing concentrations of lead, PCBs, and DDT since their use was restricted in the 1970s, whereas polycyclic aromatic hydrocarbons (PAHs) generally are increasing in urbanizing watersheds with increased motor vehicle traffic.

Even low levels of urbanization can affect aquatic ecosystems, as shown by stream-ecology studies in the Anchorage, Birmingham, Boston, Chicago, DaytonCincinnati, Los Angeles, Philadelphia-Trenton, and Salt Lake City metropolitan areas. For example, aquatic insect communities are affected when watersheds reach about 5 percent impervious area in Anchorage (which correlates with a population density as low as 125 to 250 people per square mile).

\section{5 years of science for America}

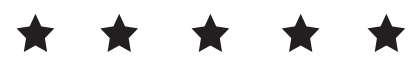

Printed on recycled paper 
The influence of natural features can be substantial. For example, mercury concentrations are affected by the amount of wetlands and the presence of sulfur, carbon, organic matter, and dissolved oxygen in the soils and water. Concentrations of total mercury were higher in sediment in urban watersheds in the Boston metropolitan area than in adjacent, more forested watersheds in Maine and New Hampshire; however, concentrations of total mercury in fish (most of which was the most toxic form, methylmercury) were higher in fish in the forested watersheds, in large part because of the larger amount of wetlands.

NAWQA analyses detect very low levels of pesticides and volatile organic compounds (VOCs). There was widespread detection of these compounds, albeit often at low concentrations, in river basins and aquifer systems across a wide range of landscapes and land uses. In the mostly agricultural Lower Tennessee River Basin, for example, 52 different pesticides were detected in streams and rivers, and VOCs were detected in about 67 percent of sampled springs and wells that tap underlying carbonate aquifers.

Streams and ground water in watersheds with significant agriculture or urban development usually contain mixtures of VOCs, nutrients, pesticides, and their chemical breakdown products. In Oahu, for example, VOCs and pesticides were detected together in more than half of sampled public-supply wells, with one exception. Few contaminants were detected in Honolulu due to a century of urban planning and watershed protection that directs intensive chemical use and storage away from upland recharge areas of the city.

Some contaminants occur naturally, even in relatively pristine areas like the Yellowstone River Basin in Wyoming and Montana. Elevated concentrations of phosphorus in streams are derived from igneous and marine sedimentary rocks; elevated concentrations of arsenic most likely result from sedimentary rocks in contact with geothermal waters.

The NAWOA Program has launched a second round of monitoring, research, and assessment in $\mathbf{4 2}$ of the $\mathbf{5 1}$ study units. The main goals are to determine trends at many of the sites, fill critical gaps in the characterization of water-quality conditions, and increase understanding of natural and human factors that affect water quality.

For additional information, contact NAWOA Chief, 703-6485012 dnmyers@usgs.gov

For NAWOA publications, maps, data, and descriptions of program activities, visit water.usgs.gov/nawqa

\section{Findings provide information for decisions at local, State, and national levels}

The USGS provides ... top quality data and accurate reporting that both the farming community and the environmental community can trust. NAWQA's ability to look at water quality over the long term helps to evaluate the effectiveness of watermanagement decisions, conservation activities, and certain farming practices that are used to reduce sediment and runoff of agricultural nutrients and chemicals from fields. Jeff Loser, National Leader for Clean Water Programs, USDA Natural Resources Conservation Service

The combined surface- and ground-water quality and ecological assessments of the Flint River Basin by the Lower Tennessee River Basin NAWQA Program have heightened our awareness of how vulnerable our water resources are due to karst features of the watershed. These technical, interdisciplinary assessments of watershed conditions have helped focus our watershed restoration efforts within the Flint River Basin. Susan Weber, Flint River Conservation Association

Data from the NAWQA Program supplied critical information for Ohio EPA's Total Maximum Daily Load (TMDL) effort in the Stillwater River Basin, and will continue to provide valuable data for future TMDLs in other sub-basins of the Great Miami River. Robert Miltner, Aquatic Ecologist, Ohio Environmental Protection Agency

The NAWQA Program has filled a tremendous void in the pesticide data that the State of Alabama must acquire in the development of the USEPA-mandated State Pesticide Management Plans. Tony Cofer, Program Director-Pesticide Division, Alabama Department of Agriculture and Industries

Alaska's social and economic fabric is inextricably bound to the health of our salmon habitat and water quality. The NAWQA Program has played a critical role in helping policy makers, businesses and citizens better understand the complexities of our watersheds, and as a result, we now have better tools to manage our salmon and water resources for future generations. Bob Shavelson, Executive Director, Cook Inlet Keeper, Alaska

The NAWQA study has been very valuable to the U.S. Environmental Protection Agency's New England regional water programs. The study has provided contaminated sediment data, which will be incorporated into our National and regional sediment inventories; has highlighted the importance of arsenic in drinking water wells in New England; and has established relationships between land use and environmental quality of rivers and streams, including flow, nutrient status, and biological communities. The data from, and the monitoring approaches of, the study will help the USEPA in its monitoring and regulatory roles. Matthew Liebman, Environmental Biologist, U.S. Environmental Protection Agency-New England

This fact sheet is based on Hamilton, P.A., Miller, T. L., and Myers, D.N., 2004, Water quality in the Nation's streams and aquifers-Overview of selected findings, 1991-2001: U.S. Geological Survey Circular 1265, 20 p. 